\title{
Implikasi Pendidikan dari Hadits Riwayat Muslim No. 4803 terhadap Peran Orangtua dalam Mendidik Aqidah Anak
}

\section{Balqis Amany Hasan*, Khambali}

Prodi Pendidikan Agama Islam, Fakultas Tarbiyah dan Keguruan, Universitas Islam Bandung, Indonesia.

*balqisamanyhasan@gmail.com, khambali@unisba.ac.id

\begin{abstract}
This study aims to (1) know the opinion of muslim hadits lecturers about every child born in a fitrah state (2) revealing the essence contained in the Hadith of muslim history No. 4803. (3) expressing the opinion of experts on the role of parents in educating children aqidah (4) find pedagogical implications in the Hadith of the Muslim History concerning the role of parents in educating children Aqidah Islamic Education Perspective. The results suggest that the essence of the Hadith of Muslim History No. 4803 is (1) Every child is in a straight fitrah that is to know Allah SWT as His God. (2) The religion of a child cannot be separated from the way parents educate and nurture. (3) The child's religion is also influenced by the surrounding environment in which the child lives and socializes. The implications of Islamic education based on Hadith of Muslim History No. 4803 on the role of parents in educating children aqidah are as follows (1) Determine prospective life partners. (2) Educating children islamicly.
\end{abstract}

Keywords: H.R Muslim No. 4803, Parenthood, Aqidah

Abstrak. Penelitian ini bertujuan untuk (1) mengetahui pendapat pensyarah hadits Muslim tentang setiap anak terlahir dalam keadaan fitrah (2) mengungkap esensi yang terkandung dalam Hadits Riwayat Muslim No. 4803 (3) mengemukakan pendapat para ahli mengenai peran orangtua dalam mendidik aqidah anak (4) menemukan implikasi pedagogis dalam Hadits Riwayat Muslim mengenai peran orangtua dalam mendidik aqidah anak Perspektif Pendidikan Islam. Hasil penelitian mengemukakan bahwa esensi dari Hadits Riwayat Muslim No. 4803 adalah (1) Setiap anak berada dalam fitrah yang lurus yakni mengenal Allah SWT sebagai Tuhan-Nya. (2) Agama seorang anak tidak lepas dari cara orangtua dalam mendidik dan membina. (3) Agama anak juga dipengaruhi oleh lingkungan sekitar tempat anak tinggal dan bersosialisasi. Adapun implikasi pendidikan Islam berdasarkan Hadits Riwayat Muslim No 4803 terhadap peran orangtua dalam mendidik aqidah anak adalah sebagai berikut (1) Menetukan calon pasangan hidup. (2) Mendidik anak secara Islami.

Kata Kunci: H.R Muslim No. 4803, Peran Orangtua, Aqidah 


\section{A. Pendahuluan}

Makhluk yang paling sempurna didunia adalah manusia. Dengan kesempurnaan ini menjadikan manusia sebagai khalifah di dunia yang memiliki tugas agar mendapatkan kemaslahatan. Maka tugas manusia tidaklah mudah, oleh karena itu Allah memberikan potensi dalam diri manusia agar dapat digunakan dalam kehidupannya. Potensi-potensi ini dapat mengarahkan manusia pada dua hal yaitu kebaikan dan keburukan, karena dapat mendorong pada dua kecenderungan ini, maka manusia memerlukan pendidikan yang dapat mengarahkannya kepada pebuatanperbuatan baik. Dengan memberikan pendidikan agama dapat mengarahkan manusia sesuai dengan fitrah dasar dan potensi yang ada dalam dirinya.

Jadi pada dasarnya semua manusia membawa fitrah dasar yaitu bertauhid kepada Allah SWT. Kata fitrah disini sebagaimana dalam hadits

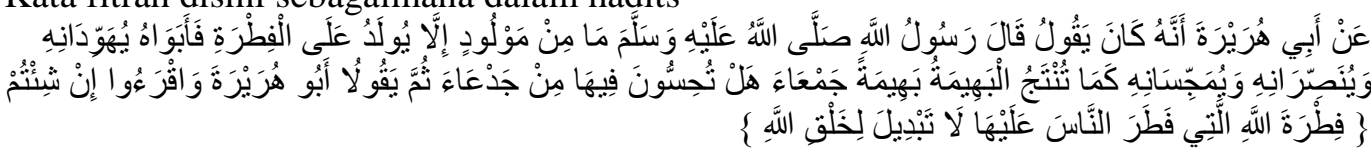

Artinya: Abu Hurairah, dia berkata; "Rasulullah shallallahu 'alaihi wasallam telah bersabda: 'Seorang bayi tidak dilahirkan (ke dunia ini) melainkan ia berada dalam kesucian (fitrah). Kemudian kedua orangtuanyalah yang akan membuatnya menjadi Yahudi, Nasrani, ataupun Majusi -sebagaimana hewan yang dilahirkan dalam keadaan selamat tanpa cacat. Maka, apakah kalian merasakan adanya cacat? ' Lalu Abu Hurairah berkata; 'Apabila kalian mau, maka bacalah firman Allah yang berbunyi: '...tetaplah atas fitrah Allah yang telah menciptakan manusia menurut fitrahnya itu. Tidak ada perubahan atas fitrah Allah.' (QS. Ar Ruum (30): 30).

Berdasarkan hadits diatas pada dasarnya anak membawa potensi atau biasa disebutnya juga fitrah bertauhid kepada Allah SWT, adapun manusia itu nantinya murtad atau berpaling dari Tuhan-Nya, itu disebabkan karena adanya pengaruh dari luar seperi pendidikan yang diberikan orangtua kepadanya kurang tepat, lingkungan sekolah, interaksi antar teman yang dapat memberikan pengaruh buruk pada dirinya, atau juga lingkungan masyarakat yang kurang baik yang dapat menjadikan dirinya berpaling dari Allah SWT.

Contoh sebagaimana dalam berita IDN TIMES Jateng, terdapat 7 artis yang pindah agama setelah menikah.

"Keharmonisan dalam rumah tangga dapat berkurang karena adanya perbedaan. Salah satu perbedaanya adalah karena agama. Maka tidak heran, banyak orang atau artis yang melakukan konvensi agama, agar sama dengan pasangannya. Dengan tujuan agar terhindar dari konflik rumah tangga."

Berdasarkan faktor-faktor yang disebutkan diatas, Islam memerintahkan kepada orangtua untuk mengajarkan pendidikan agama kepada anaknya agar dapat mengembangkan potensi dasarnya yaitu bertauhid kepada Allah. Selain itu juga Rasulullah SAW, menekankan pendidikan pertama yang harus diajarkan kepada anak adalah pendidikan aqidah.

Pada perkembangan zaman saat ini, banyak anak yang keluar dari fitrahnya yaitu bertauhid kepada Allah karena faktor pergaulan. Bila kita perhatikan anak yang didik dengan baik oleh orangtuanya dan disekolah yang baik akan berbeda dengan anak yang tidak didik dengan baik dan disekolahkan yang kurang tepat. Ini membuktikan bahwa perkembangan seorang individu itu terantung bagaimana orangtua mendidiknya dan tergantung bagaimana lingkungan mempengaruhinya.

Oleh karena itu, Rasulullah SAW, menekankan pentingnya peran orangtua dalam memberikan pendidikan kepada anak. Karena dari pendidikan yang diberikan orangtua kepada anak dapat menjadikan anak tetap berpegang teguh pada fitrahnya yang lurus atau malah berpaling. Maka, jika fitrah tauhid tersebut dipupuk dan dibina dengan baik maka anak akan menjadi orang yang taat beragama, begitu pun sebaliknya apabila fitrah tauhid tidak dibina dengan baik, maka anak akan jauh ataupun tidak beragama. Zuharirini, (seperti dikutip Mardiyah, 2015:111).

Selain itu, kewajiban orangtua tidak hanya memberikan pendidikan aqidah saja, tetapi juga mengembangkan potensi-potensi yang lain, menjaga anak dari lingkungan yang dapat memberikan pengaruh buruk terhadap dirinya, menanamkan nilai-nilai Islam, agar dimana pun 
anak berada serta dalam keadaan apapun, anak akan tetap pada fitrahnya yang lurus yaitu bertauhid kepada Allah SWT.

Berdasarkan uraian diatas latar, maka penelitian ini bertujuan dari sebagai berikut:

1. Mengungkapkan pendapat pensyarah Hadits Muslim No. 4803tentang setiap anak terlahir dalam keadaan fitrah.

2. Mengetahui esensi yang terkandung dalam Hadits Riwayat Muslim No. 4803.

3. Mengungkapkan pendapat para ahli mengenai peran orangtua dalam mendidik aqidah anak.

4. Menjelaskan implikasi pendidikan dari Hadits Riwayat Muslim No. 4803 mengenai peran orangtua dalam mendidik aqidah anak perspektif pendidikan Islam.

\section{B. Metodologi Penelitian}

\section{Metode dan Pendekatan}

Penelitian ini menggunakan pendekatan kualitatif dan metode yang digunakan dalam penelitian ini adalah deskriptif analitik. Metode deskriptif analitik adalah mengumpulkan semua data yang telah diperoleh saat penelitian ini dilakukan yang kemudian mendeskripsikan hasil penelitianya dengan menganalisis dalam mentuk paragraf. (Sugiyono. 2009:29)

Tujuan metode ini dilakukan agar dapat mendeskripsikan tentang peran orangtua dalam mendidik aqidah anak melalui cara dengan mengumpulkan informasi dan menafsirkannya.

Selain itu, juga metode ini dipilih agar dapat menjelaskan isi kandungan hadits riwayat muslim no. 4803, sehingga dapat dimengerti kandungan di dalamnya serta dapat di implimentasikan dalam kehidupan.

\section{Teknik Penelitian Hadits}

Menurut Saifuddin ASM (2017:254-270) terdapat 5 metode yang dapat digunakan:

1. Metode Tausiq yaitu untuk menyelidiki keotentikan hadits.

Metode ini bertujuan untuk menyelidiki apakah hadits tersebut otentik atau tidak, dengan cara melihat dalam al-Mashadir al-Ashiyah.

2. Metode Takhrij yaitu meneliti sanad dan matan hadits.

Metode ini bertujuan untuk menunjukan sumber hadits melalui sanad dengan pejelasan kedudukan perowinya.

3. Metode Tashih yaitu untuk meneliti validasi hadits.

Metode ini bertujuan untuk mengetahui validasinya apakah hadits ini dapat diterima atau tidak. Dengan cara menyelidiki sanad dan matanya. Apabila hadits tersebut telah diakui keabsahannya, baik sanad, ataupun kualitas isinya, maka dapat dianggap valid.

4. Metode Tahlili yaitu untuk menganalisi Syarah Hadits.

Metode ini menjelaskan ma'na ma'na yang terkandung dalam isi hadits sesuai dengan pendapat para ahli hadits.

5. Metode Takwil.

Setelah menguraikan pemdapat para persyarah hadits, kemudia diambil pelajaran atau esensi yang terkandung didalamnya.

\section{Hasil Penelitian dan Pembahasan}

\section{Setiap anak dilahirkan dalam keadaan fitrah yang lurus yakni tauhid.}

$$
\text { مَا مِنْ مَوْلُودٍ إِلَّا يُوَلَدُ عَلَى الْفِطْرَةٍ }
$$

Artinya: Seorang bayi tidak dilahirkan (ke dunia ini) melainkan ia berada dalam kesucian (fitrah)

Dari potongan hadits riwat Muslim diatas Allah SWT menciptakan seluruh manusia dalam keadaan suci atau memiliki fitrah. Kata fitrah menurut Abdullah, disebut dengan istilah agama yang lurus. Maksudnya semua manusia yang dilahirkan sudah membawa potensi memiliki agama yang lurus yaitu agama tauhid (Islam). (Santosa, 2018:142). Sedangkan menurut Jalaluddin, fitrah tauhid ditunjukan dengan adanya keinginan manusia untuk patuh pada Tuhan-Nya. Pada hakikatnya setiap manusia memiliki sifat tersebut. (Jalaluddin, 2003:18). Begitu pun menurut kitab syarah Fathul Mu'in, bahwa semua anak keturunan adam terlahir 
dalam keadaan Islam, karena mereka telah melakukan perjanjian yang telah diadakan antara Allah dan manusia ketika berada di alam ruh, mereka bersaksi bahwa tidak ada Tuhan yang berhak disembah selain Allah, sebagaimana ditegaskan dalam Q.S Al-Araf: 172.

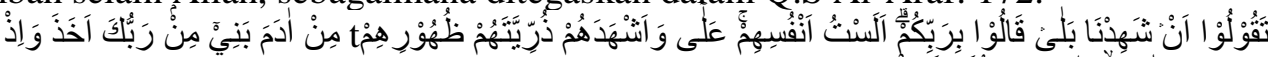

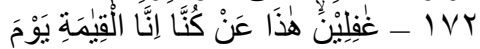

Artinya: "Dan (ingatlah), ketika Tuhanmu mengeluarkan keturunan anak-anak Adam dari sulbi mereka dan Allah mengambil kesaksian terhadap jiwa mereka (seraya berfirman): "Bukankah Aku ini Tuhanmu?" Mereka menjawab: "Betul (Engkau Tuhan kami), kami menjadi saksi". (Kami lakukan yang demikian itu) agar di hari kiamat kamu tidak mengatakan: "Sesungguhnya kami (bani Adam) adalah orang-orang yang lengah terhadap ini (keesaan Tuhan)."

Jadi Allah menciptakan seluruh manusia dalam keadaan hanif begitu pun agama Islam, agama yang hanif. Maka dari itu manusia tidak memiliki alasan untuk tidak beriman kepada Allah. Menurut al-Maraghi dalam Santosa, mengatakan fitrah berkecenderungan untuk dapat menerima kebenaran. Karena fitrah manusia cenderung untuk mencari dan menerima kebenaran, meskipun hanya ada dalam hati kecilnya. Ada masanya manusia menemukan kebenaran tetapi karena faktor luar yang mempengaruhi menjadikan manusia berpaling dari kebenaran yang didapatnya. (Santosa, 2018:143). Pengaruh luar yang dimaksud seperti orangtua dan lingkungan sekitarnnya.

Namun jika semua mausia itu sadar, introspeksi, dan menyadari kekuasaan Allah, maka ia akan menyadari dalam dirinya terdapat ajakan untuk mencari ridho Allah SWT.

\section{Agama anak tidak lepas dari cara orangtua dalam mendidik dan membina.}

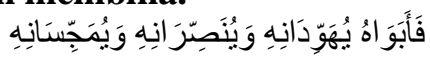

Artinya: Kemudian kedua orangtuanyalah yang akan membuatnya menjadi Yahudi, Nasrani, ataupun Majusi.

Dari potongan hadits diatas pada saat seseorang terlahir dalam keadaan Islam, adanya perubahan keyakinan itu terjadi karena kedua orangtuanya, baik melalui pengajaran, motivasi, bimbingan, dan pendidikan yang diberikan kepadanya. Begitupun menurut kitab Syarah AlKaukabut Wahhaj, jika kedua orangtuanya Yahudi, maka mereka akan menjadikannya Yahudi. Begitu pun jika kedua orangtuanya Nasrani dan Yahudi, maka mereka akan menjadikannya mengikuti keyakinannya.

Perubahan diumpakan oleh Rasulullah SAW, pada redaksi

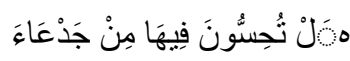

Artinya: "Sebagaimana hewan yang dilahirkan dalam keadaan selamat tanpa cacat"

Menurut kitab syarah Al-Kaukabul Wahhaj Maknanya sebagaimana hewan yang dilahirkan induknya dalam keadaan sempurna anggota tubuhnya tanpa ada kekurangan seperti terputus telinganya atau yang lainnya, sedangkan adanya kecacatan terjadi setelah kelahirannya.

Jadi, adanya perubahan keyakinan pada anak saat di dunia diumpakan dengan adanya perubahan pada ciptaan fisiknya dengan adanya cacat atau aib.

Selain itu, berdasarkan hadits terusebut tidak menjelaskan jika kedua orangtua Islam, maka anaknya menjadi Islam. Karena pada hakikatnya seluruh manusia dilahirkan dalam keadaan beragama Islam. Adapun anak itu menjadi Yahudi, Nasrani, dan Majusi karena pendidikan, bimbinga, dan motivasi yang diberikan kepadanya. Sebagaimana menurut Gilbert Highest dalam Jalaluddin (2019:253), menyatakan bahwa kebiasaan-kebiasaan anak itu terbentuk dari pendidikan orangtua. Karena dari anak mulai bangun tidur hingga tidur kembali anak berada di bawah pengawasan pendidikan orangtua.

Ini membuktikan bahwa orangtua mempunyai peran besar dalam menentukan anak kedepannya serta berperan besar dalam menentukan arah keyakinan anaknya. Walaupun semua anak diciptakan dalam keadaan bertauhid kepada Allah (Islam). Namun saat di dunia nantinya akan menganut keyakinan seperti apa, tergantung bagaimana orangtua mendidik dan membinanya. 


\section{Agama anak juga dipengaruhi lingkungan sekolah dan tempat anak tinggal.}

$$
\text { فَأَبَوَ اهُ }
$$

Artinya: "kedua orangtua."

Dalam kitab syarah Fathul Mu'in, mengungkapkan bahwa adapun dikhususan penyebutan kedua orangtua yang menyebabkan terjadinya perubahan keyakinan pada seseorang adakalanya disebabkan faktor lain, seperti lingkungan sekolah dan tempat anak tinggal.

Lingkungan sekolah juga ikut berperan dalam membentuk keimanan pada anak sebagaimana menurut Gillesphy dan Young dalam Jalaluddin (2019:257), membuktikan bahwa pendidikan agama yang diberikan oleh keluarga lebih berpengaruh dalam menentukan arah keimanan dan membentuk perilaku pada anak, tetapi pendidikan agama yang diberikan disekolahpun ikut berpengaruh dalam membentuk dan menentukan keimanan seorang anak. Hal ini dibuktikan dengan adanya tokoh-tokoh agama yang berasal dari sekolah-sekolah agama seperti pondok pesantren.

Dari lingkungan sekolah ini akan terbentuk pergaulan antar siswa, yang mana teman pun turut berperan dalam membentuk keimanan pada anak. Sebagaimana dalam hadits

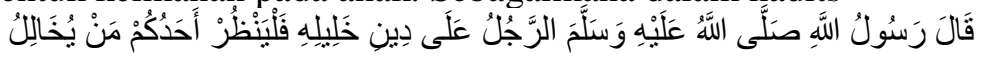

Artinya: Rasulullah Shallallahu 'alaihi wa salam bersabda: "Seseorang itu akan mengikuti agama temannya, karenanya hendaklah salah seorang diantara kalian mencermati kepada siapa ia berteman." (H.R at-Tirmidzi no 2300).

Berdasarkan hadits terseut maka orangtua berkewajiban untuk lebih selektif dalam menentukan dimanaanak sekolah dan dengan siapa anak berteman. Karena untuk membiasakan serta menumbuhkan nilai-nilai ajaran agama pada anak tidak hanya orantua saja yang memberikan pengaruh, melainkan juga teman bermainnya.

Selain itu tempat tinggal anak pun turut berperan. Karena lingkungan tempat tinggal yang sangat berkaitan dengan kehidupan seseorang dalam sehari-harinya. Dalam lingkungan ini anak akan berinteraksi dan memberikan pengaruh satu sama lain. Contoh anak yang tinggal di lingkungan yang sering mengadakan kegiatan-kegiatan agama seperti taraweh, tadarusan, pengajian dll akan terdapat perbedaan dengan anak yang berada di lingkungan yang sering melakukan maksiat. Ini membuktikan bahwa perkembangan seorang individu itu tergantung bagaimana orangtua mendidiknya dan bagaimana lingkungan mempengaruhinya.

Menurut Buchor dalam Jalaluddin (2019:259), Jika pertumbuhan fisik akan berhenti saat anak mencapai usia dewasa, tetapi pertumbuhan psikis akan berlangsung seumur hidup. Maka masa pendidikan disekolah hanya berjalan selama waktu tertentu. Sebaliknya, pendidikan dimasyarakat akan berjalan seumur hidup. Ini menunjukan besarnya pengaruh masyarakat dalam mempengaruhi perkembangan keimanan seseorang.

Berdasarkan penjelasan diatas maka orangtua, lingkungan sekolah, dan tempat tingga sama-sama memiliki berperan dalam memberikan pengaruh pada anak. Apakah anak akan menjadi manusia yang taat pada pada agama Allah atau sebaliknya. Dengan demikian perlunya kerjasama antar ketiga lingkungan tersebut untuk mendidik anak-anak agar dapat menciptakan generasi yang shalih dan shalihah, berilmu, berakhlak, berkualitas baik jasmani dan rohani.

Implikasi Pendidikan dari Hadits Riwayat Muslim No. 4803 Terhadap Peran Orangtua Dalam Mendidik Aqidah Anak.

- Menentukan Calon Pasangan Hidup.

Fase ini erat kaitannya dengan tujuan pernikahan. Dalam Islam tujuan pernikahan adalah menciptakan generasi-generasi yang shalih dan shalihah, berakhlak dan berkualitas. Dan untuk, untuk mewujudkan hal itu berawal dari pendidikan keluarga yang diberikan. Dan untuk menentukan kualitas pendidikan sangat ditentukan pada saat menetukan calon pasangan hidup.

Karena menurut teori nativisme, tidak hanya fisik yang dapat menjadi genetik, tetapi juga psikis, seperti sifat, kecerdasan, karakter dll. Ini menunjukan bahwa pasangan sangat berperan besar dalam membentuk, menumbuh kembangkan seorang individu. Menurut Purwanto, tingkat pendidikan orangtua juga turut memberikan pengaruh pada kualitas pendidikan yang dilakukan kepada anaknya, yang akhirnya akan berpengaruh juga pada kualitas masyarakat itu sendiri. 
Keluarga yang dibangun berlandasrkan ajaran-ajaran agama maka akan menciptakan genarasi-generasi yang shalih dan shalihah. Dan untuk mewujudkan hal itu, maka harus dimulai dengan memilih pasangan yang taat pada agama. Dan untuk mendapatkan pasangan seperti itu harus dimulai dari diri sendiri.

Selain tiu berbeda dengan anak yang tumbuh dari pasangan atau keluarga yang memiliki dua keyakinan berbeda.

Dimana anak yang tumbuh dari keluarga yang berbeda tidak akan mendapatkan pendidikan agama dengan sempurna. Karena menurut Muhaimin hasil penrlitiannya menyatakan bahwa anak belajar melalui indera penglihatannya yaitu melalui keteladanan.dan untuk memberikan pendidikan agama pada anak bersifat keteladanan. Anak akan belajar berdoa, beribadah, membaca kita suci dll, melalui orangtuanya.

Sedangkan orangtua akan saling berebut pengaruh kepada anaknya, agar ia mengikuti agama yang diyakininya. Pada akhirnya anak akan mengalami kebingungan dalam memilih agama yang akan dianutnya. Biasanya anak akan memilih agamanya pada saat remaja. Jika pada saat remaja masih mengalami kebingungan, maka ia akan menjadi orang yang tidak taat pada agama, bahkan sampai akhirnya berdampak pada konvensi agama dan cenderung mengalami kebingungan dalam memilih agama yang di percayanya benar.

Maka dalam Islam untuk memilih pasangan harus sekufu, yang salah satunya adalah agama agar tercipta kebahagiaan, ketenangan, ketentraman, dan mendapatkan pahala yang berlimpah dari Allah SWT. Oleh karena itu memilih pasangan hidup itu sangat penting dalam menentukan kualitas pendidikan yang akan diberikan pada anak, yang akhirnya akan sangat menetukan kualitas masyarakat, bangsa atau negara itu sendiri.

- Mendidik Secara Islami.

Islam menempatkan pendidikan aqidah diatas segalanya. Jika pendidikan pertama yang diberikan kepada anak bukan aqidah, maka kelak anak akan jauh dari Tuhan dan agamanya. Karena aqidah merupakan dasar keimanan yang harus diyakini dalam hati, diucapkan dengan lisan, dan dibuktikan dengan perbuatan.

Sebagaimana nasehat Luqman kepada anaknya untuk tidak menyekutukan Allah SWT, karena syirik itu merupakan kezaliman yang sangat besar. Maka dari itu, pendidikan aqidah yang pertama kali yang harus diajarkan kepada anak. Bila diibaratkan dengan bangunan aqidah adalah pondasi bangunan yang dapat mempengaruhi seluruh bangunan lainnya. Oleh karena itu, pendidikan aqidah sudah dapat diajarkan pada saat usia 0-24 tahun. Mengapa sampai usia 24 tahun? Karena kematangan jiwa beragama seseorang itu bisanya tidak akan terjadi sebelum usia 24 tahun. Jadi menurut agama usia remaja itu mulai dari 13-24 tahun. Dimana pada usia ini jiwa beragamanya masil labil.

Adapun pendidikan aqidah yang dapat dilakukan orangtua pada anak, sebagai berikut:

1. Sejak dalam kandungan.

Setiap prilaku ibu sangat berpengaruh pada pembentukan kepribadian anak, maka pendidikan yang dapat dilakukan, yaitu:

a. Melaksanakan shalat, agar mengingat Allah, berserah diri dan mendapatkan ketenangan karena kondiri psikis ibu berpengaruh pada anak.

b. Membaca alquran, selain ibadah dan mendapatkan pahala, bayi dalam kandungan sudah dapat mendengarnya terutama pada usia kandungan lima bulan.

c. Sedekah dapat menyadari bahwa segala sesuatu di dunia ini milik Allah SWT.

d. Berdizikir dan berdo'a, akan memberikan ketenangan pada bayi dalam kandungan.

2. Sejak usia 0-2 tahun

a. Membuka kehidupan anak dengan mengadzankan ditelinga kanan dan iqomat di telingan kiri, agar yang pertama kali didengar oleh anak adalah kalimat-kalimat kebesaran Allah SWT.

b. Memberikan nama yang baik. Karena nama adalah doa dan harapan orangtua.

c. Aqiqah, sebagi bentuk rasa syukur kita kepada Allah SWT.

d. Menyusui, bertujuan untuk menumbuhkan kasih sayang yang dapat berpengaruh pada perkembangan jiwa anak. 
e. Memberikan makan dan minum yang halal, karena akan berdampak pada perkembangan jasmani dan rohaninya.

f. Saat anak dapat berbicara ajarkan anak untuk mengucapkan Bismillah saat hendak melakukan sesuatu dan Alhamdulillah saat hendak selesai melakukan sesuatu.

3. Sejak usia 2-6 tahun.

a. Mengajarkan anak untuk menghafal doa-doa sehari-hari

b. Mengajarkan untuk menghafalkan surat-surat pendek.

c. Mengajarkan gerakan-gerakan shalat dan wudhu.

d. Memberikan pemahaman bahwa segala yang ada dilangit dan bumi adalah ciptaan Allah.

Semua ini dapat dilakukan dengan menggunakan metode pembiasaan dan keteladanan.

4. Sejak usia 7-12 tahun.

Fase ini diajarkan adab dan melatih anak untuk melaksanakan kewajiban-kewajibannya sebagai seorang muslim.

a. Membiasakan anak mengerjakan ajaran agama seperti shalat, puasa, sedekah, dan sebagainya.

b. Mebiasakan anak laki-laki shalat dimasjid dan anak perempuan berjamaan dirumah bersama ibunya.

c. Mengajarkan untuk berzakat dan infaq

Semua ini dapat dilakukan dengan menggunakan metode keteladanan, pembiasaan, dan nasehat.

5. Sejak usia 12-24 tahun

a. Membiasakan anak mengikuti kegiatan-kegiatan keagamaan.

Anak pada usia ini perlu arahan dan bimbingan secara ekstra dari orangtua. Karena usia ini, anak berada pada tahap usia labil dan sedang mencar jati diri. Oleh karena itu diperulaknya pengawasan dari orangtua.

\section{Kesimpulan}

Berdasarkan pembahasan pada penelitian ini, menurut para persyarah hadits pada dasarnya semua cucu keturunan Adam dalam keadaan milah Islam atau bertauhid kepada Allah. Hal ini dapat terjadi karena mereka telah bersaksi bahwa tidak ada Tuhan yang berhak disembah selain Allah SWT. Adapun anak itu murtad atau berpaling saat di dunia, itu dapat terjadi karena pendidikan, motivasi, bimbingan yang diberikan orangtua pada anaknya.

Begitupun menurut para ahli pendidikan bukan berarti pada saat anak bersaksi bahwa Allah adalah Tuahnnya, kemudian ketika dilahirkan ia langsung mengetahui siapa Tuhan dan apa agamanya, melainkan perlunya bimbingan, arahan, dan pendidikan yang diberikan kepadanya. Begitu pun menurut Gilber dalam Jalaluddin, bahwa kebiasaan-kebiasaan anak itu terbentuk dari pendidikan orangtua. Ini membuktikan bahwa pendidikan yang diberikan orangtua kepada anak akan menentukan masa depan anak serta keyakinan anak.

Adapun implikasi yang dapat dilakukan dalam mendidik anak yaitu pertama, menentukan pasangan hidup karena pasangan sangat berperan dalam menentukan kulaitas pendidikan yang akan diberikan pada anak. Kedua, mendidik anak secara Islami, dalam mendidik aqidah pada anak dapat dimulai sejak dalam kandungan hingga usia 24 tahun. Karena menurut jalaluddin kematangan agama seseorang dapat terjadi setelah usia tersebut.

\section{E. Acknowledge}

Terimakasih kepada pembimbing yang selalu memberikan arahan serta dukungan sehingga peneliti bisa menyelesaikan penelitian ini. Teriakasih juga kepada para penguji telah memberikan masukan pada penelitian ini.

\section{Daftar Pustaka}

[1] ASM, S. A. (2017). Pengantar Ilumu Hadits dan Cara Berteladan Pada Rasul. Bandung: Komunitas Kajian Alquran dan Hadits.

[2] Jalaluddin. (2003). teologi pendidikan . jakarta: raja grafindo perasada. 
78 Balqis Amany Hasan, et al.

[3] Jalaluddin. (2019). teologi pendidikan . jakarta: raja grafindo perasada.

[4] Mardiyah. (2015). Peran Orangtua Dalam Pendidikan Agma Terhadap Pembentukan Kepribadian Anak. Jurnal Kependidikan, Vol: 3, No:2.

[5] Santosa, H. (2018). fitrah based education mengembangkan pendidikan sejati selarah fitrah misi hidup dan tujuan hidup. bekasi: yayasan cahaya mutiara timur.

[6] Sugiyono. (2009). Metode Penelitan KOMBINASI. Bandung: Alfabeta 